\title{
Histopathology of fatal adenovirus infection of the respiratory tract in young children
}

\author{
D. M. O. BECROFT \\ From the Princess Mary Hospital for Children, Auckland, New Zealand
}

SYNOPSIS Type 7 adenoviruses were isolated from lung tissue obtained at the necropsies on five children aged 8 to 15 months. The clinical and radiological findings were those of bronchiolitis and pneumonia. Four children had an extensive necrotizing bronchitis and bronchiolitis. The surviving bronchial epithelium, and all bronchial epithelium in the fifth case, was proliferating. There was evidence that this proliferation was a virus-induced effect and not reparative. There was virus tropism to alveolar lining cells with a pneumonia showing mononuclear cellular reaction, necrosis, and hyaline membranes. Distinctive necrotizing lesions were found in the bronchial glands of all cases. Two contrasting types of intranuclear inclusions were present in all lesions and their significance and inter-relationships are discussed. These pathological changes are specific for infections by a limited number of adenovirus serotypes.

The usual clinical effects of adenovirus infection are well defined. Various serotypes have been identified as the cause of minor febrile, respiratory, conjunctival, and pharyngeal infections occurring at all ages (Stuart-Harris, 1962). Epidemics of infection may occur, particularly in closed communities, but otherwise the adenoviruses account for only a minority of respiratory illnesses in the general population (van der Veen, 1963). These infections usually are mild and there is less certainty about the role of the virus in causing severe disease of the lower respiratory tract. During adenoviral epidemics evidence of this infection in cases presenting with pneumonia does not prove a causal relationship (Maisel, Pierce, Crawford, and Rosenbaum, 1962). On the other hand, there are a number of reports of the isolation of the virus from the lung tissue of children dying of bronchopneumonia and the similarity of the histopathological findings in these cases has supported an adenoviral aetiology.

In Auckland, since 1959, type 7 adenoviruses have been isolated from the lungs of five children dying from acute lower respiratory tract infections. In this paper the clinical, histopathological, and epidemiological features of the five cases are described, compared with those in previous reports, and the specificity of the pathological findings is examined further.

Received for publication 24 January 1967.

\section{CASE REPORTS}

Findings in individual cases are presented in the Table. All patients were infants aged 8 to 15 months. Four were male, two were European, and three Polynesian. All were well-grown, well-nourished children with no history of undue susceptibility to respiratory infections and, with the exception of case 4 , no previous illnesses of significance.

CASES 1, 2, 3, AND 5 These children had closely similar illnesses. There had been respiratory symptoms of increasing severity for three to four days. One child developed a morbilliform rash two days before the respiratory symptoms and two had diarrhoea. On admission these four children had temperatures of $37 \cdot 8^{\circ} \mathrm{C}$. to $40 \cdot 6^{\circ} \mathrm{C}$. and tachycardia. Distressed, rapid respirations, marked wheeze, rib recession, and auscultatory findings led to a provisional diagnosis of bronchiolitis in all patients. Two children had additional signs suggesting pneumonia. The chest radiographs showed a generalized increase in lung markings indicative of peribronchial or interstitial inflammation. The lung fields were hyperventilated in three patients and three had more extensive shadowing suggesting consolidation or collapse, particularly in the lower zones. Two children had mild hypochromic anaemias. The results of other investigations are tabulated.

All patients were treated with antibiotics, three were given adrenal corticosteroids, and one child was digitalized. One or more antispasmodics were used in each case. Oxygen was given, but respirations were not assisted. Treatment had little effect, fever persisted, and there 
TABLE

FATAL CASES OF ADENOVIRUS INFECTION

\begin{tabular}{|c|c|c|c|c|c|}
\hline & Case 1 & Case 2 & Case 3 & Case 4 & Case 5 \\
\hline $\begin{array}{l}\text { Date of admission } \\
\text { Age-sex } \\
\text { Race } \\
\text { Presenting symptoms }\end{array}$ & $\begin{array}{l}\text { August } 1959 \\
12 \text { months - male } \\
\text { Maori } \\
\text { Morbilliform }\end{array}$ & $\begin{array}{l}\text { March } 1960 \\
8 \text { months - male } \\
\text { European }\end{array}$ & $\begin{array}{l}\text { June } 1960 \\
13 \text { months - male } \\
\text { European } \\
\text { Cough }\end{array}$ & $\begin{array}{l}\text { September } 1960 \\
10 \text { months - male } \\
\text { Nuie Islander } \\
\text { 'III' } 4 \text { or } 5 \text { days }\end{array}$ & $\begin{array}{l}\text { August } 1963 \\
15 \text { months - Female } \\
\text { Maori }\end{array}$ \\
\hline Presenting symptoms & $\begin{array}{l}\text { Morbilliform } \\
\text { rash - } 5 \text { days } \\
\text { 'Respiratory } \\
\text { infection' }-3 \text { days }\end{array}$ & $\left.\begin{array}{l}\text { Cough } \\
\text { Wheeze } \\
\text { Dyspnoea } \\
\text { Fever }\end{array}\right\} 4$ days & $\left.\begin{array}{l}\text { Cough } \\
\text { Wheeze } \\
\text { Dyspnoea } \\
\text { Fever }\end{array}\right\} 3$ days & 'IIl' $\quad 4$ or 5 days & $\left.\begin{array}{l}\text { Cough ? } 3 \text { weeks } \\
\text { Wheeze } \\
\text { Dyspnoea }\end{array}\right\} 3$ days \\
\hline $\begin{array}{l}\text { Clinical diagnosis } \\
\text { on admission }\end{array}$ & $\begin{array}{l}\text { Bronchiolitis, } \\
\text { bronchopneumonia }\end{array}$ & Bronchiolitis & Bronchiolitis & Bronchopneumonia & $\begin{array}{l}\text { Bronchiolitis, } \\
\text { pneumonia }\end{array}$ \\
\hline Chest radiographs & $\begin{array}{l}\text { Increased lung } \\
\text { markings, hyper- } \\
\text { ventilation }\end{array}$ & $\begin{array}{l}\text { Increased lung } \\
\text { markings, hyper- } \\
\text { ventilation, } \\
\text { consolidation } \mathbf{R} \text {. } \\
\text { upper lobe. }\end{array}$ & $\begin{array}{l}\text { Increased lung } \\
\text { markings, hyper- } \\
\text { ventilation } \\
\text { consolidation L. } \\
\text { lower lobe }\end{array}$ & 一 & $\begin{array}{l}\text { Consolidation both } \\
\text { lower zones }\end{array}$ \\
\hline White blood cells & $\begin{array}{l}15,000 / \text { c.mm. } \\
\text { ( } 91 \% \text { neutrophils) }\end{array}$ & $\begin{array}{l}\text { 7,500/c.mm. } \\
\text { (50\% neutrophils) }\end{array}$ & - & 一 & $\begin{array}{l}\text { 3,800/c.mm. } \\
\text { (27\% neutrophils) }\end{array}$ \\
\hline Throat swabs & - & Commensals only & 一 & 一 & $\begin{array}{l}\text { Staphylococcus aureus } \\
\text { (also from nose } \\
\text { and faeces) }\end{array}$ \\
\hline Other & $\begin{array}{l}\text { Urine analysis } \\
\text { normal }\end{array}$ & C.S.F. normal & 一 & 一 & $\begin{array}{l}\text { Blood culture sterile, } \\
\text { urine analysis normal }\end{array}$ \\
\hline Antibiotics & $\begin{array}{l}\text { Chloramphenicol, } \\
\text { novobiocin }\end{array}$ & $\begin{array}{l}\text { Chloramphenicol, } \\
\text { tetracycline } \\
\text { erythromycin }\end{array}$ & $\begin{array}{l}\text { Chloramphenicol, } \\
\text { penicillin, streptomycin }\end{array}$ & Penicillin (oral) & $\begin{array}{l}\text { Erythromycin, } \\
\text { tetracycline, } \\
\text { ampicillin }\end{array}$ \\
\hline $\begin{array}{l}\text { Steroids } \\
\text { Interval between }\end{array}$ & Prednisone, A.C.T.H. & - & Prednisone & 一 & Hydrocortisone \\
\hline $\begin{array}{l}\text { (1) Onset and death } \\
\text { (2) Admission and } \\
\text { death }\end{array}$ & $\begin{array}{l}7 \text { days } \\
41 \text { hours }\end{array}$ & $\begin{array}{l}7 \text { days } \\
3 \text { days }\end{array}$ & $\begin{array}{l}4 \text { days } \\
31 \text { hours }\end{array}$ & $\begin{array}{l}\text { 4-5 days } \\
15 \text { minutes }\end{array}$ & $\begin{array}{l}? 6 \text { days } \\
3 \text { days }\end{array}$ \\
\hline
\end{tabular}

was inexorably increasing respiratory distress with restlessness, cyanosis, and tachycardia. Two children had convulsions terminally. Although case 3 was severely ill his death was sudden and unexpected. All patients died within three days of admission to hospital, after illnesses lasting four to seven days from the first symptoms.

CASE 4 This 10-month-old infant died within 15 minutes of his admission and treatment was limited to resuscitative measures. The only history obtained was that he had been ill for four to five days and had been given penicillin by mouth. Two weeks before he had been discharged from hospital after an illness diagnosed as bronchopneumonia with bronchospasm. The onset of this illness was similar to that described above and, although his recovery had appeared complete, it is possible that the fatal illness was a relapse of this earlier infection.

\section{NECROPSY FINDINGS}

All five children were well-developed and wellnourished and there were no skin lesions or other external features of note. In two cases the pleural cavities contained small serous effusions. All lungs were voluminous and maintained this overexpanded state after removal from the pleural cavities. The lungs of cases $1,2,4$, and 5 contained multiple, mostly small, brick-red or purple-red areas of consolidation (Fig. 1). These lesions were irregularly distributed through all lobes, but were more extensive posteriorly and in the lower lobes. Case 4 was most severely affected, showing consolidation of the greater part of both lower lobes, the right middle lobe, and the posterior part of the right upper lobe. Intervening tissue was either emphysematous, mildly congested and oedematous or, less frequently, atelectatic. There was no consolidation in the lungs of case 3 , but overinflation was particularly severe and there was an unsually extensive interstitial and mediastinal emphysema (Fig. 2). Interlobular septa throughout the lungs of this case were expanded by large air-filled blebs and there were bullae up to $2 \mathrm{~cm}$. in diameter at the lung margins and at the hila. The soft tissues of the anter-

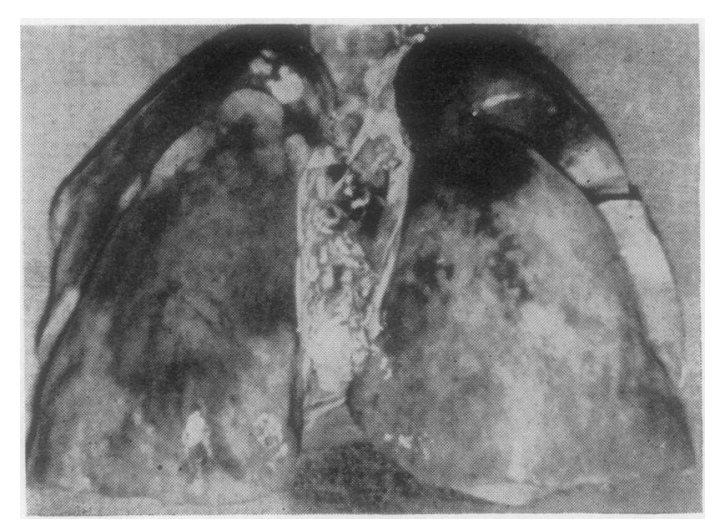

FIG. 1. Case 2. Posterior aspect of the lungs showing areas of consolidation. 


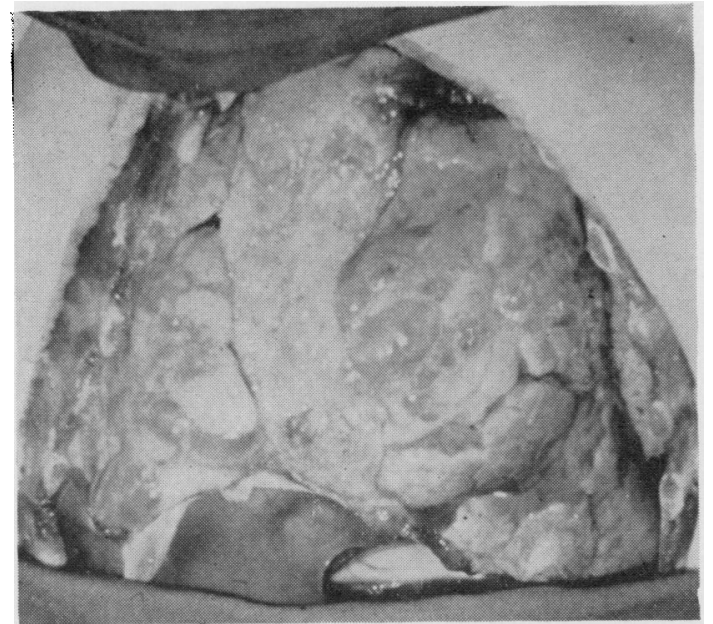

FIG. 2. Case 3. Severe interstitial emphysema and pneumo-mediastinum.

ior mediastinum were transformed into a honeycomb of air-filled spaces.

Many bronchi were filled with exudate, usually mucoid or fibrinous, but occasionally purulent or haemorrhagic. The mucosa of larger bronchi was congested and the walls of smaller bronchi were thickened and the lumina narrowed. The mucosal surfaces of the pharynx, larynx, and trachea in each case were mildly congested but there was no evidence of severe inflammation nor of ulceration. The tracheobronchial lymph nodes were enlarged, congested and oedematous in all cases. Lymph nodes elsewhere were of normal size. The spleens of cases 1,4 , and 5 were enlarged, but to less than twice the normal weight for age. Altered blood was found in the stomach, oesophagus, and respiratory passages of case 4 . Bleeding appeared to have been from small pyloric ulcers, which later proved to be due to monilial infection. These were the only abnormalities found outside the respiratory tract.

\section{HISTOLOGY}

LOWER RESPIRATORY TRACT The lesions common to these cases were characterized by cellular necrosis and by distinctive intranuclear inclusions in the surviving cells. The destructive changes frequently were accompanied or replaced by proliferation. The epithelium of the bronchial tree, the bronchial glands and the alveolar septa were affected particularly, although the severity of the lesions at each site differed considerably from case to case.

BRONCHI AND BRONCHIOLES In cases $1,2,4$, and 5 the changes were largely destructive and so extensive that no surviving bronchial or bronchiolar epithelium remained in some blocks of lung tissue. The mediumsized intrapulmonary bronchi of 1 to $2 \mathrm{~mm}$. diameter were affected most severely and only a few fragments of respiratory epithelium remained at this level of the bronchial tree. The majority of the larger intrapulmonary bronchi were at least partially ulcerated and all the residual epithelium was abnormal. There was marked exudation from the ulcerated surfaces. Some of the denuded bronchi and bronchioles had narrow lumina encircled by a thick layer of homogeneous eosinophilic P.A.S.positive material which, apart from its bulk, resembled the typical hyaline membrane present in the alveolar ducts (Fig. 3). More often the exudate filled the lumen and was pleomorphic, including in various proportions similar hyaline material, mucus, fibrin, neutrophils, macrophages, cellular debris, and desquamated epithelial cells, some of the latter bearing inclusions (Fig. 4). The ulceration included the basement membrane but rarely extended more deeply. The congested and swollen lamina propria of the larger bronchi was infiltrated by lymphocytes, plasma cells, macrophages, and a few neutrophils, while a similar but more intense infiltration involved the full thickness of the walls of many smaller bronchi and bronchioles, and the adjacent alveoli (Fig. 4). Muscle bundles and elastic fibres were widely dispersed by this inflammatory reaction. Full-thickness necrosis was rare, however, and was confined to a few terminal and respiratory bronchioles. Otherwise these smaller bronchioles were affected least severely. Some were entirely normal while others, although inflamed and often occluded by exudate, had an intact epithelium.

No ulceration was found in the bronchial tree of case 3 , but the respiratory epithelium of all bronchi and bronchioles showed proliferative changes (Fig. 5). There was similar proliferation of all residual epithelium in the larger bronchi of the other cases (Fig. 6). Cilia and goblet cells were absent throughout and a stratified arrangement of polyhedral cells with swollen vesicular nuclei replaced the regular pseudo-stratified columnar structure. There were occasional mitoses in the basal layers. Many cells near the surface were degenerate or were desquamating, and these often contained inclusions (Fig. 6). Alternatively, and particularly where the epithelium was six or more cells thick, the surface layers were squamous, but not keratinizing, and inclusions and desquamating cells were infrequent.

BRONCHIAL GLANDS This was the only site at which all cases had typical necrotizing lesions. The change was least severe in case 1 but in the others several degenerate acini were found about most bronchi 


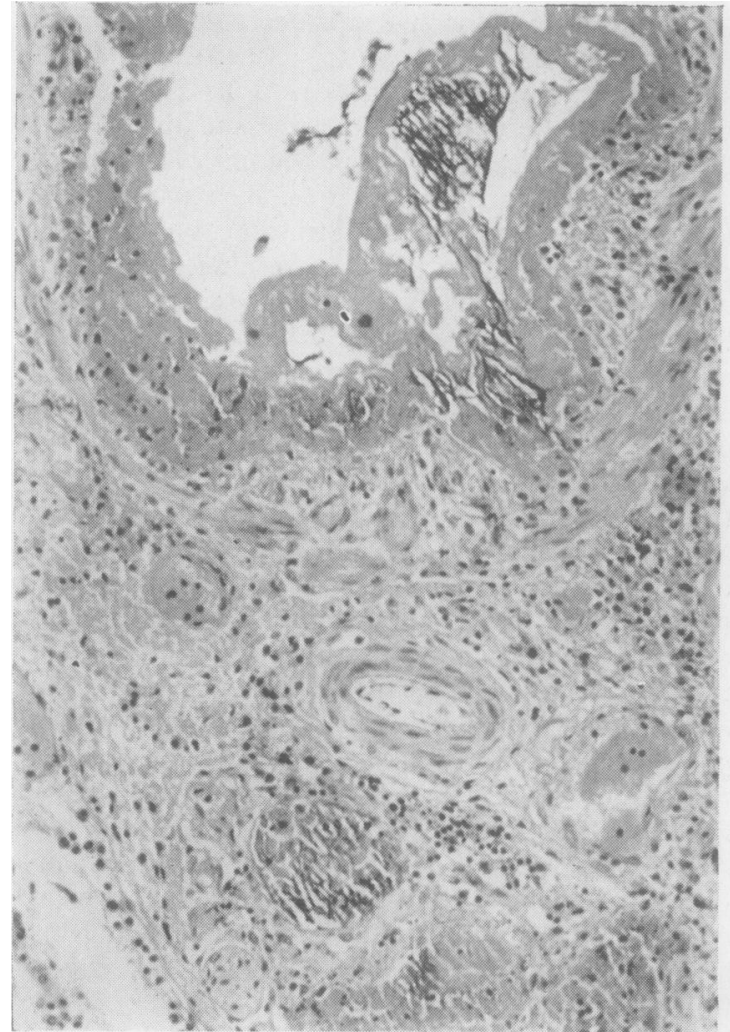

FIG. 3.

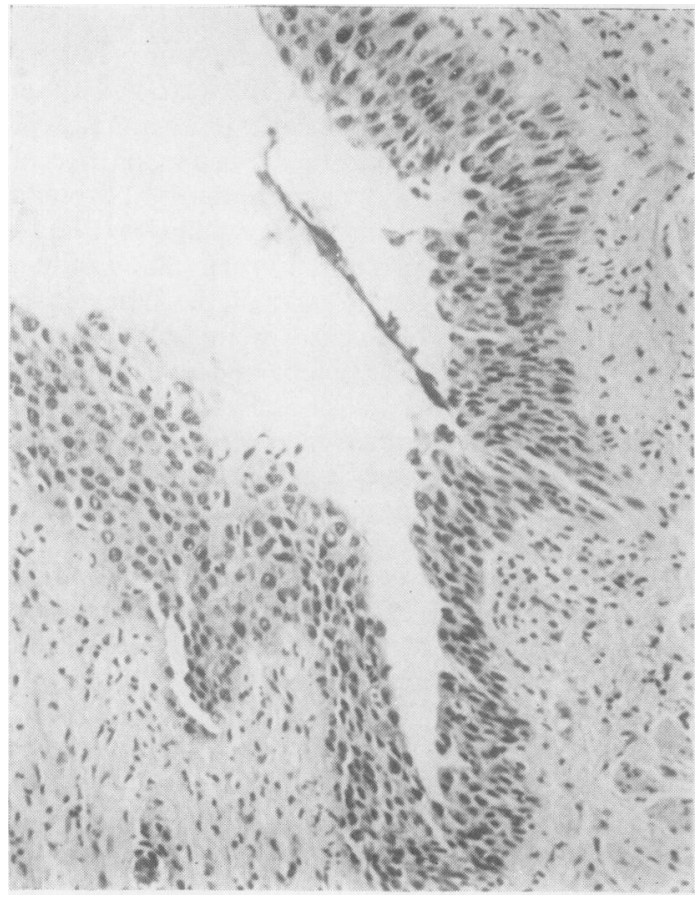

FIG. 5 .

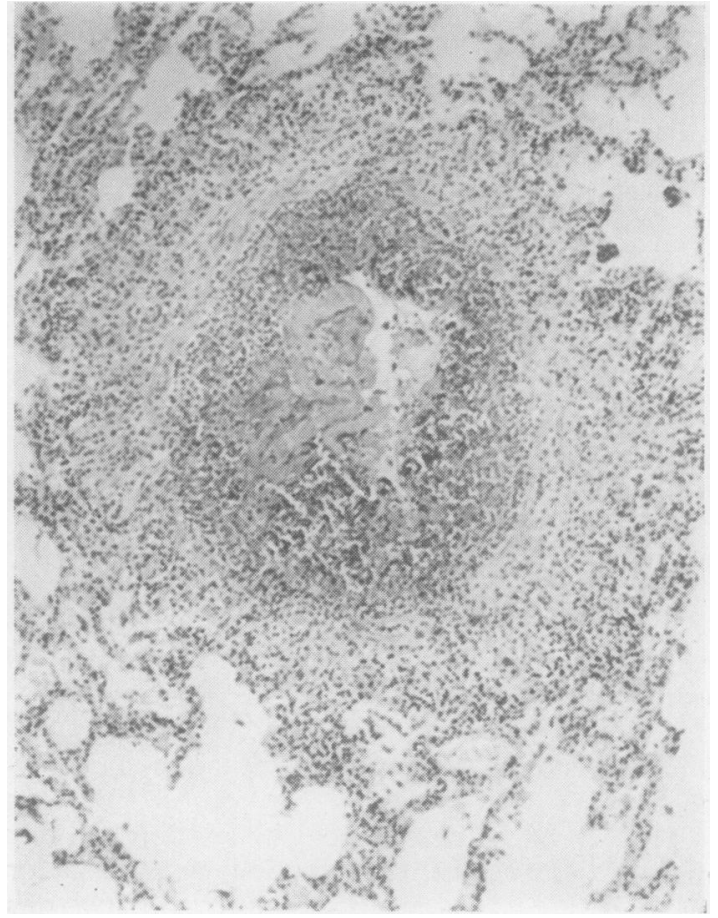

FIG. 4.

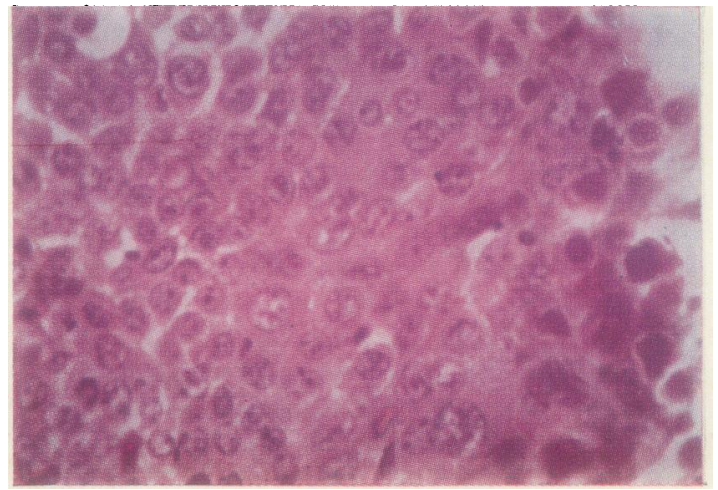

FIG. 6 .

FIG. 3. Case 4. Necrotizing bronchitis. A thick eosinophilic membrane lines the wall of a small bronchus. Bronchial glands are necrotic. Haematoxylin and eosin $\times 165$.

FIG. 4. Case 1. Necrotizing bronchiolitis. The lumen is filled with pleomorphic exudate. Alveoli are emphysematous. Haematoxylin and eosin $\times 65$.

FIG. 5. Case 3. Proliferating bronchial epithelium. Haematoxylin and eosin $\times 200$.

FIG. 6. Case 1. Proliferating bronchial epithelium. Many nuclei contain one or more discrete eosinophilic inclusions. Inclusion material is distributed diffusely in the nuclei of degenerate surface cells. Haematoxylin and eosin $\times 230$. 
sectioned (Figs. 3 and 7). The peripheral lobules, situated outside the cartilage plates, were particularly affected. Changes were focal, sometimes involving only a single acinus, but often several acini or a whole lobule were replaced by a granular eosinophilic coagulum. Both the mucous and the serous acinar cells had either been completely destroyed or were degenerate and desquamating into the lumina. Many residual cells contained inclusions (Fig. 7). The acinar basement membranes usually remained intact, but the lobular and perilobular connective tissue was heavily infitrated by lymphocytes and plasma cells. Fibrin, neutrophils, macrophages, and mucus filled other affected acini. The severity of the acinar lesions had no correlation with the degree of epithelial destruction in the associated bronchus. Changes in the larger ducts, however, were similar to those in the bronchi.

ALVEOLI The appearances were highly variable but the consolidated areas in cases $1,2,4$, and 5 had features in common. Alveoli and alveolar ducts were distended by an eosinophilic exudate part proteinaceous oedema fluid, part fibrin strands, part granular coagulum. Some of this material may have tracked down from the bronchial tree, but much was a result of focal necrosis of the alveolar septa and local inflammatory exudation. Many alveolar ducts were lined by a P.A.S.-positive hyaline membrane. There was an interstitial and intraalveolar infiltration by macrophages, lymphocytes, and plasma cells. Neutrophils were abundant in a few areas, but no bacteria were identified. In the most severely affected lung there was extensive disorganization as a result of necrosis of the cellular components of the alveolar walls and of inflammatory cells, leaving much nuclear debris mingled with eosinophilic exudate and foci of haemorrhage. Even in these areas the connective tissues of the alveolar septa were intact and no occlusive vascular lesions were detected. The consolidated areas often were bounded by interlobular septa and a necrotic terminal bronchiole was identified centrally in others. Less severely affected alveolar tissue was congested and oedematous, with or without fibrinous exudation and mononuclear reaction. Alveolar lining cells were swollen, many to cuboidal shape, particularly in the alveoli immediately adjacent to inflamed bronchiolar walls. Inclusion-bearing cells were abundant in the necrotic areas. Some cells were lying free but others were attached to remnants of the alveolar septa and in the less degenerate tissue it was clear that inclusions were developing in the swollen alveolar lining cells (Fig. 8a). Other free-lying, inclusion-bearing cells may have been macrophages or cells desquamated from the respira- tory epithelium. No section of the lung was entirely normal, as in addition to widespread bronchial and bronchiolar lessions other alveolar tissue was either emphysematous or atelectatic (Fig. 4). There was severe alveolar and interstitial emphysema throughout the lungs of case 3 .

INCLUSIONS Two types of nuclear change were attributed to viral proliferation. The first was a diffuse accumulation in the nucleus of homogeneous, amphophilic or basophilic, phloxinophilic, strongly Feulgen-poitive material (Figs. 7b and 8a). This was not sharply demarcated from the surrounding nuclear chromatin. The second was a discrete, eosinophilic, phloxinophilic, but Feulgen-negative inclusion, surrounded by a clear zone or 'halo' in the nuclear chromatin (Figs. 6 and $8 \mathrm{~b}$ ). These differed from the type A viral inclusions of herpes simplex or varicella in that the outlines were irregular and poorly demarcated and the surrounding 'halo' incomplete (Fig. 8b). There was a marked difference in the size of the two types of inclusions. The majority of discrete eosinophilic inclusions were less than $5 \mu$ in diameter and the nuclei were only slightly enlarged. By contrast the diffuse Feulgen-positive inclusions filled nuclei ranging from normal size up to giant forms as much as $14 \mu$ in diameter. The latter were a striking feature even under low magnification (Fig. 7a). Amphophilia was more evident in the larger inclusions, but Feulgen-positivity persisted in the majority. A thin rim of chromatin remained about the large inclusions, sometimes separated by a narrow pale zone, but a distinct 'halo' was unusual. Many inclusions in desquamating or degenerate cells were crenated, vacuolated, or fragmenting. With increasing eosinophilia of cytoplasm and disappearance of all nuclear basophilia, other cells were transformed into homogeneous eosinophilic bodies accompanying the debris within the lumina of many alveoli, glands, and bronchioles.

The interrelationships of the two types of intranuclear inclusions were not clear. Both types were found together in some tissues and could therefore have been different stages of a single developmental sequence (Fig. 8a). However, the large diffuse inclusions predominated in alveoli and in glands and a sequence could be traced from normal nuclei to the largest inclusions, without the discrete eosinophilic inclusions appearing to be a necessary part of this sequence. Alternatively, the eosinophilic inclusions often occurred alone in the proliferating bronchial epithelium and here a second sequence could be traced from the appearance of small, sometimes multiple, eosinophilic particles within the vesicular chromatin, through Feulgen-negative inclusions of increasing size until the nucleus was 


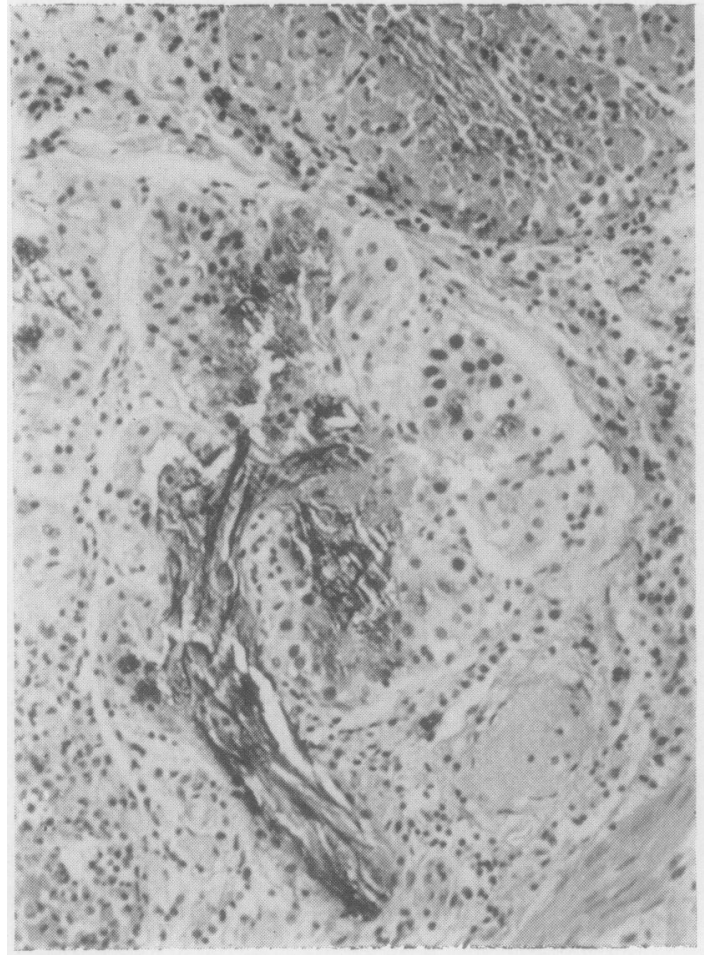

FIG. 7a.

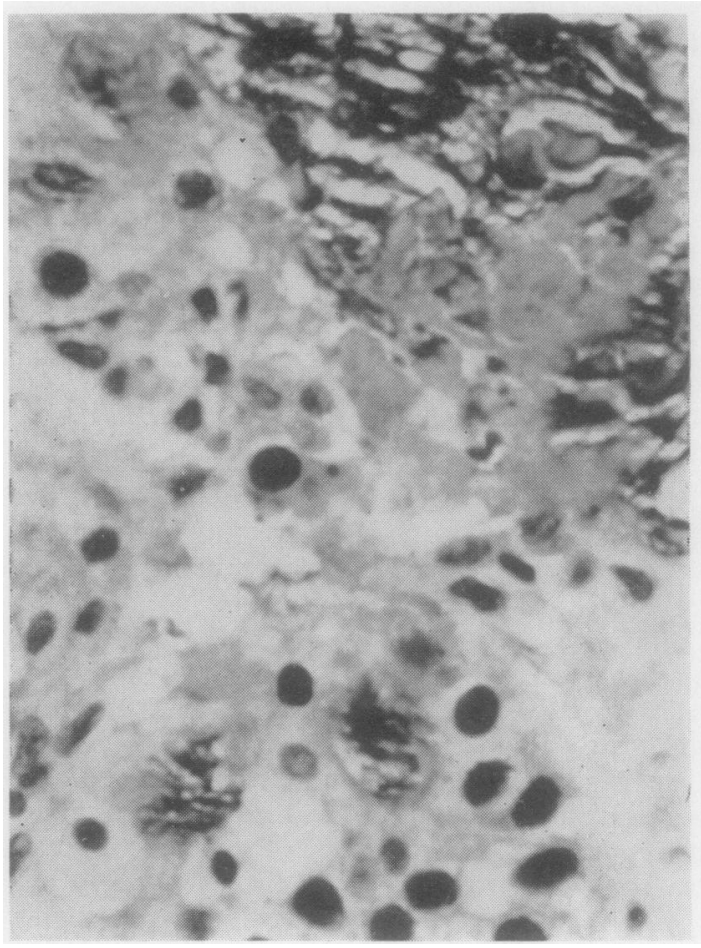

FIG. $7 b$.

FIG. 7. Case 2. Bronchial glands. Haematoxylin and eosin. (a) Some acini are completely necrotic. Other acinar cells contain large basophilic inclusions $\times 200$.

(b) Detail of (a) showing large basophilic inclusions and necrotic material in lumen $\times 675$.

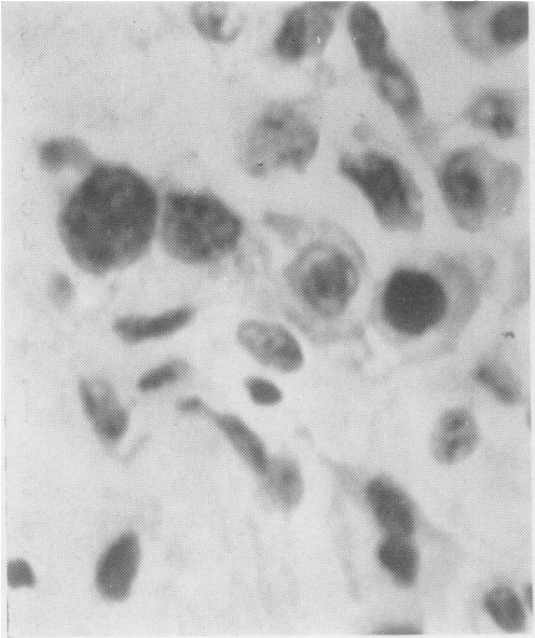

FIG. 8 a.

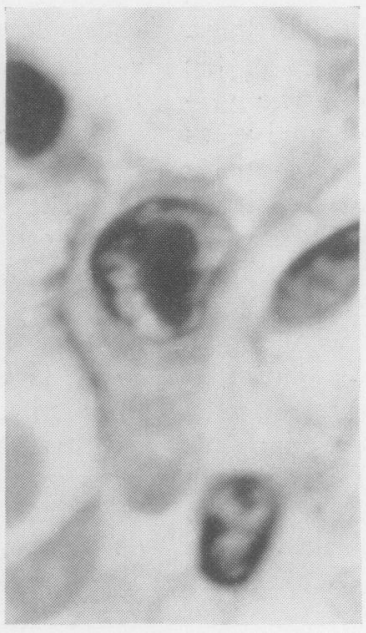

FIG. $8 \mathrm{~b}$.
FIG. 8. Case 5. Intranuclear inclusions in alveolar tissue Haematoxylin and eosin. (a) Four adjacent alveolar lining cells containing inclusions. The discrete eosinophilic inclusion with 'halo' contrasts with the large diffuse basophilic or amphophilic inclusions $\times 1,000$. (b) An eosinophilic inclusion at higher magnification to show irregular outline and incomplete 'halo' $\times 2,000$. 
eventually filled or the cell degenerated (Fig. 6). The discrete eosinophilic inclusions occasionally may have developed from the diffuse type, but the reverse probably did not occur and in general the two types appeared to represent alternative and largely independent reactions of the nucleus.

UPPER RESPIRATORY TRACT The epithelium of the trachea in case 1 showed proliferative changes and intranuclear inclusions similar to those in the bronchi. In other cases the tracheal epithelium had lost cilia and had a tattered appearance, but there was no ulceration and no inclusions were detected. The tracheal glands in cases 4 and 5 showed typical necrotizing lesions with inclusions. Sections from the tongue, posterior pharynx, tonsils, and larynx in three cases revealed minor subepithelial inflammatory changes, but there were no specific lesions.

OTHER ORGANS The swollen tracheo-bronchial lymph nodes present in all cases had dilated sinuses containing many large macrophages. Although occasional cells had large hyperchromatic nuclei no inclusions were detected. Lymphoid tissue elsewhere was normal. The liver, spleen, kidney, pancreas, adrenals, thyroid, and myocardium were sectioned in all cases and the small and large intestines in four. The only abnormality found was patchy centrilobular necrosis in the liver of case 5 but this appeared due to anoxia and not to virus infection. No evidence of meningo-encephalitis was found in the three patients in whom the central nervous system was examined.

\section{VIROLOGY}

Viruses were isolated from lung tissue obtained at the necropsies of all five cases and from a throat swab taken from case 5 on the day of her admission to hospital. Primary inoculations were into Hela or HEp 2 tissue cultures in which cytopathic changes appeared promptly and on passage. The viruses isolated from cases $1,2,3$, and 4 were investigated further at the Department of Virus Diseases, National Institutes of Health, Bethesda, Md., where all were identified as type 7 adenoviruses by haemagglutination inhibition techniques (Rosen, 1960). The adenoviruses isolated more recently from the throat and lung of case 5 were identified as type 7 by neutralization techniques (Grayston, Johnston, Smith, and Loosli, 1956). The antisera used were prepared by a technique similar to that described by Rowe, Huebner, Hartley, Ward, and Parrott (1955).

\section{DISCUSSION}

The extent of the necrotizing lesions in bronchial and bronchiolar epithelium determined the clinical course of four patients. The initial clinical and radiological findings were those of bronchiolitis and the patients' death followed progressively severe anoxia largely due to airway obstruction. It is doubtful if even the best modern methods of respiratory management could have maintained patency of the bronchial tree against such an outpouring of exudate. The presence of viral inclusions in alveolar lining cells proved a true viral pneumonia in each case, but clinically the alveolar lesions appeared to be of secondary importance.

The fifth patient had an intact bronchial epithelium and might have survived had he not suddenly developed interstitial pulmonary emphysema and pneumomediastinum. In this case there was widespread proliferation of the bronchial epithelium which, in the absence of ulceration, clearly was not reparative. In all cases the presence of viral inclusions in the proliferating cells indicated that this change was virus induced. Hyperplasia of bronchial epithelium infected by adenoviruses has also been observed in vitro (Maddi, 1963) and is of interest in relation to the oncogenic properties of type 7 adenovirus (Larson, Girardi, Hilleman, and Zwickey, 1965). The necrotizing lesions in bronchial glands were a striking feature of all cases and of particular diagnostic importance in case 3 in which they provided the first evidence of an adenoviral aetiology.

The uniformity of these pathological findings is strong evidence that the type 7 adenovirus isolated from each case was the primary aetiological agent and not an incidentally detected prevalent virus. Additional points confirming this relationship are: (1) that similar changes have been described in other cases from which certain adenovirus serotypes have been isolated; (2) that the intranuclear inclusions resemble those produced by these adenoviruses in other cell systems; (3) that no other infectious agent is known to cause this combination of lesions; and (4) that there was no evidence of a concurrent adenovirus epidemic.

FATAL ADENOVIRUS INFECTION The first reports of the isolation of adenoviruses from children dying with pneumonia were from France, two case with similar pathological findings reviewed by Chany, Lépine, Lelong, Le-Tan-Vinh, Satgé, and Virat (1958). By 1964 Wright, Beckwith, and Gwinn were able to collect reports of 28 fatal cases of adenovirus infection in children, but there were only three further descriptions of the pathology in cases from which viruses had been isolated, one 
from Japan (Kawai, 1959) and two from the United States (Benyesh-Melnick and Rosenberg, 1964; Wright et al., 1964). However, Wright et al. did not include the reports of a large number of deaths due to pneumonia during an epidemic of adenovirus infection in China in 1958 and 1959 (Teng, 1960), when 3,398 children presented with pneumonia at one hospital in Peking, 528 died, and Hsiung (1963) later described the pathology of 40 of these cases in which adenoviruses were isolated from lung tissue. With the inclusion of other reports from Russia (Dreizen, Zhukova, and Kniazeva, 1960) and Germany (Güthert, Meerbach, and Wöckel, 1964) there are pathological descriptions of at least 60 cases from which adenoviruses have been isolated. The majority of these adenoviruses have been type 7 and all but one of the remainder type 3. Most patients were previously healthy infants under 1 year of age. Necrotizing bronchitis and bronchiolitis, and a pneumonia with mononuclear cellular reaction, hyaline membranes, and necrosis have been described in varying detail in all cases from which type 7 or type 3 viruses were isolated. These changes appear identical to those found in the present series, but not all authors have described the acidophilic granular necrosis of mucous glands and hyperplastic epithelium which were a feature of all the Auckland cases. The presence of inclusions or the isolation of a virus from the appropriate tissue strongly supports the adenoviral aetiology of meningo-encephalitis (Chany et al., 1958), hepatitis (Benyesh-Melnick and Rosenberg, 1964) and lymphadenitis (Kawai, 1959) in some cases, but these appear to be unusual complications.

INCLUSIONS All reports of the pathology of type 7 infection describe intranuclear inclusions in the lesions in the respiratory tract and most make a distinction between the smaller eosinophilic forms with surrounding halo and the much larger basophilic inclusions which fill greatly expanded nuclei. There has, however, been a difference of opinion on the interrelationship of the two types of inclusion, with each referred to as the late or mature form and the other as the precursor. The conclusion stated above, that these were alternative and largely independent reactions of the nucleus to infection, receives support from consideration of the cytological changes induced in tissue cultures by type 7 adenoviruses (Boyer, Denny, Miller, and Ginsberg, 1960). In tissue cultures the mature inclusions are large, basophilic, and strongly Feulgen-positive. They contain up to 10 times as much D.N.A. as uninfected cells and large amounts of viral antigen and infective virus. In contrast to the sequence in herpes simplex infection there is no later stage in which the inclusions become eosinophilic and Feulgen-negative. In vivo as in vitro it is likely that the large basophilic Feulgen-positive inclusion is the mature form, typical of a cell heavily, and presumably lethally, infected by adenovirus.

There is no stage described in tissue culture corresponding exactly to the solitary eosinophilic inclusion, but multiple small eosinophilic inclusions appear as an early cytopathic effect when there is little infective virus and viral antigen present. This suggests that the eosinophilic inclusions found in vivo occur in cells which are less heavily infected and can be correlated with the observation in the present series that these inclusions were found particularly in the proliferating bronchial epithelial cells. Many of the nuclear changes observed in tissue cultures, including crystalline structures and 'flower' or 'rosette' forms of mature inclusions, were rare in these cases, but this difference may be due to the poor cytological detail in necropsy material compared with that in monolayer preparations.

DIFFERENTIAL DIAGNOSIS There is agreement on the major pathological features of type 7 infection and that similar changes are induced by the type 3 virus. These lesions have considerable specificity and in necropsy material a firm diagnosis will usually be possible on histological grounds alone. The two serotypes are members of a subgroup of adenoviruses sharing many biological properties but fatal infections by other serotypes of the group have yet to be described. Cases apparently having fatal infections by the less closely related serotypes 1 and 21 have not had extensive necrotizing lesions nor similar inclusions (Deinhardt, May, Calhoun, and Sullivan, 1958; Clarke, Corner, Gambier, Macrae, and Peacock, 1964).

Other virus infections may induce intranuclear inclusions in the respiratory tract but these will not usually cause diagnostic difficulty. Although some of the adenovirus inclusions resemble the type A inclusions of varicella and herpes simplex the lesions of the disseminated forms of the latter infections are typically focal and involve other organs, while the larger basophilic inclusions characteristic of adenovirus infection will be absent. Cytomegalic inclusion disease will be readily excluded because of the difference in the clinical setting, in the localization of lesions in the respiratory tract, and a marked difference in size and form of all but the degenerate cytomegalic inclusions. In morbilli there may be some destructive changes in the respiratory epithelium and bronchial glands, plus small amphophilic intranuclear inclusions, but these inclusions will be in multinucleated epithelial giant cells which also contain prominent cyto- 
plasmic inclusions. Confusion between the two diseases is more likely to be on clinical than pathological grounds because of morbilliform rashes caused by adenovirus infection Chany et al., 1958).

Many pathological features of types 3 and 7 infection closely resemble those due to the influenza viruses. Necrotizing lesions in the respiratory epithelium of similar extent, depth, and maximum localization in smaller bronchi have been described in influenza uncomplicated by bacterial infection (Walsh, Dietlein, Low, Burch, and Mogabgab, 1961). Necrosis of cells in bronchial glands (Spencer, 1962) and tropism to alveolar lining cells (Hers and Mulder, 1961) have also been reported. Fatal influenza infection is rare in infants, but histological differentiation from adenoviral infection would rest largely on the demonstration of typical inclusions in the latter.

The more recently identified organisms causing the majority of childhood respiratory infectionsthe rhino-viruses, the respiratory syncytial virus, the para-influenza viruses, and the Eaton agentwould not have been detected by the methods used to isolate adenoviruses from these cases. Little is known of the pathology of these rarely fatal infections, particularly that due to the rhino-viruses and Eaton agent, but it appears unlikely that they would have caused such widespread necrotizing lesions in the bronchi, or have induced intranuclear inclusions. The respiratory syncytial virus is the major cause of bronchiolitis in infancy, but in the few cases reported the bronchial epithelium has shown syncytium formation and the inclusions were cytoplasmic (Adams, Imagawa, and Zike, 1961; Holzel, Parker, Patterson, Cartmel, White, Purdy, Thompson, and Tobin, 1965). The bronchial epithelium does not appear to have been severely affected in fatal cases of infection by para-influenza viruses (Ishida, 1957; Arrobio, 1964). The differing pathological effects of adenoviruses and other respiratory viruses parallel the changes, necrotizing or otherwise, induced in organ cultures of respiratory epithelium (Tyrrell and Hoorn, 1965).

EPIDEMIOLOGY Several studies have demonstrated a low incidence of antibodies to type 7 adenoviruses in childhood, indicating that sporadic infection is uncommon at this age (van der Veen, 1963). This is not one of the serotypes commonly latent in nasopharyngeal lymphoid tissue. Nevertheless, epidemic infection of children is well documented and although the incidence of serious lower respiratory tract infection has been low in some epidemics (Sterner, 1962), others have provided the majority of the fatal cases previously reported. This variability in severity is unexplained, as is the maximum occurrence of fatal cases in an age group generally little affected by this virus. The epidemiological basis of the Auckland cases is obscure. Four presented within 13 months, but at three-to-six-month intervals and without geographical relationship. There is no indication from the records of hospital admissions that there was an unusually high incidence of any category of childhood respiratory infection during this 13 months. Although adenoviruses were isolated from other patients, none were type 7 . It is possible that the virus was widespread in latent form (Andrews, 1964), but the special susceptibility of these previously healthy children remains unexplained.

I wish to thank Dr. Alice Bush, Dr. Elizabeth Hughes, Dr G. T. Fox, and Dr. W. R. Lang; Dr. Selwyn Hills and Dr. J. F. Burton for their direction of studies in the Virus Department of the Central Laboratory, Auckland Hospital Board, and to Captain Paul D. Parkman of the National Institute of Health, Bethesda, Md. for further virus studies; Mr. R. J. Patterson for technical assistance and Mr. A. D. Fraser for assistance with photography.

\section{REFERENCES}

Adams, J. M., Imagawa, D. T., and Zike, K. (1961). J. Lancet, 81, 502. Andrewes, C. H. (1964). Science, 146, 1274.

Arrobio, J. (1964). Clin Proc. Child. Hosp. (Wash.) 20, 298.

Benyesh-Melnick, M., and Rosenberg, H. S. (1964). J. Pediat., 64, 83. Boyer, G. S., Denny, F. W. Jr., Miller, I., and Ginsberg, H. S. (1960). J. exp. Med., 112, 865.

Chany, C., Lépine, P., Lelong, M., Le-Tan-Vinh, Satgé, P., and Virat, J. (1958). Amer. J. Hyg., 76, 367.

Clarke, S. K. R., Corner, B. D., Gambier, D. M., Macrae, J., and Peacock, D. B. (1964). Brit. med. J., 1, 1536.

Deinhardt, F., May, R. D., Calhoun, H. H., and Sullivan, H. E. (1958). Arch. intern. Med., 102, 816.

Dreizen, R. S., Zhukova, E. K., and Kniazeva, L. D. (1960). Vop. Okhrany. Materin. Dets., 5, 19.

Grayston, J. T., Johnston, P. B., Smith, M. E., and Loosli, C. G. (1956). J. infect. Dis., 99, 188.

Güthert, H., Meerbach, W., and Wöckel, W. (1964). Z. ges. inn. Med., $19,865$.

Hers, J. F. P., and Mulder, J. (1961). Amer. Rev. resp. Dis. 83, (no 2, pt. 2), 84.

Holzel, A., Parker, L., Patterson, W. H., Cartmel, D., White, L. L. R., Purdy, R., Thompson, K. M., and Tobin, J. O'H. (1965). Brit. med. J., 1, 614.

Hsiung, C.-C. (1963). Chin. med. J., 82, 390.

Ishida, N. (1957). Ann. N.Y. Acad. Sci., 67, 299.

Kawai, K. (1959). Jap. J. exp. Med., 29, 359.

Larson, V. M., Girardi, A. J., Hilleman, M. R., and Zwickey, R. E. (1965). Proc. Soc. exp. Biol. (N.Y.) 118, 15.

Maddi, F. V. (1963). Ann. Inst. Pasteur, 104, 43.

Maisel, J. C., Pierce, W. E., Crawford, Y. E., and Rosenbaum M. J. (1962). Amer. J. Hyg., 75, 56.

Rosen, L. (1960). Ibid., 71, 120.

Rowe, W. P., Huebner, R. J., Hartley, J. W., Ward, T. G., and Parrott, R. H. (1955). Ibid, 61, 197.

Spencer, H. (1962). Pathology of the Lung. Pergamon Press, Oxford. Sterner, G. (1962). Acta paediat. (Uppsala), suppl. 142.

Stuart-Harris, C. H. (1962) Brit. med. J. 2, 869.

Teng, C. H. (1960). Chin. med. J., 80, 331.

Tyrrell, D. A. J., and Hoorn, B. (1965). Brit. J. exp. Path., 46, 514.

van der Veen, J. (1963). Amer. Rev. resp. Dis., 88, suppl, 167.

Walsh, J. J., Dietlein, L. F., Low, F. N., Burch, G. E., and Mogabgab, W. J. (1961). Arch. intern, Med., 108, 376. Wright, H. T., Jr., Beckwith, J. B., and Gwinn, J. L. (1964). J. Pediat.,
64, 528. 